\title{
Keniscayaan Metode Komprehensif dalam Studi Islam: Telaah Pemikiran Ali Syariati
}

\author{
Zulkifli \\ Lembaga Studi Agama dan Masyarakat Aceh (Lsama) \\ Corresponding Author, email: uleegunong16@gmail.com
}

\begin{abstract}
This article reveals Ali Shariati's thoughts on methodological issues in studying Islam. The data used are the works of Ali Shariati and relevant literature obtained from library sources and analyzed by qualitative descriptive methods and philosophical approaches. This article finds that Ali Shariati views it as important and necessary to understand Islam in various ways. According to him, the method of understanding Islam is fundamental for socio-political change and the progress of civilization. However, Ali Shariati only offers two approaches to understanding Islam, namely historical and sociological approaches. Based on these findings, this article recommends and supports the claims of urgency and necessity of comprehensive methods in Islamic studies.
\end{abstract}

Keywords: Islam, Methodology, Islamic Studies, Ali Shariati, Comprehensive Approach

\section{Pendahuluan}

Artikel ini mendiskusikan persoalan metodologi dalam studi Islam. Persoalan ini dilatarbelakangi oleh asumsi bahwa Islam bukan hanya semata agama yang dipraktekkan oleh penganutnya. Islam diyakini menjamin terwujudnya kehidupan manusia yang sejahtera lahir dan batin. Agama ini memberi petunjuk dalam al-Qur'an dan hadis bagaimana manusia seharusnya menyikapi hidup lebih bermakna (Jazuli, 2006; Gaus, 2010). Islam mengajarkan kehidupan dinamis dan progresif, menghargai akal pikiran melalui pengembangan ilmu pengetahuan dan teknologi, bersikap seimbang dalam memenuhi kebutuhan material dan spiritual, mengembangkan kepedulian sosial, menghargai waktu, bersikap terbuka, demokratis, berorientasi pada kualitas, egaliter, kemitraan, anti-feodalistik, mencintai kebersihan, mengutamakan persaudaraan, berakhlak mulia dan bersikap positif lainnya (Nata, 2006; UPI, 2007).

Islam di sisi lain memiliki banyak dimensi mulai dari keimanan, akal dan pikiran, ekonomi, politik, sampai pada kehidupan rumah tangga. Namun, berbeda dengan cita ideal tersebut, kenyataan Islam justru menampilkan keadaan yang agak bertolak belakang dengan cita ideal Islam. Ibadah yang dilakukan umat Islam seperti salat, puasa, zakat, haji, terkesan hanya berhenti pada sebatas membayar kewajiban dan menjadi lambang kesalehan, sedangkan buah dari ibadah yang berdemensi kepedulian sosial sudah kurang tampak (Chojim, 2007). Sementara itu, dikalangan masyarakat telah terjadi kesalahpahaman dalam memahami dan menghayati pesan simbolis keagamaan. Akibatnya, agama lebih dihayati sebagai penyelamatan individu dan bukan sebagai keberkahan sosial bersama.

Sejalan dengan problematika tersebut, Islam di kalangan akademisi menjadi lahan objek kajian di laboratorium berbagai bidang keilmuan. Islam dalam konteks ini bukan hanya dipandang dari aspek teologi semata, namun pada kenyataannya oleh para akademisi baik muslim maupun non-muslim (orientalis) telah didekati dengan berbagai pendekatan. Terlepas dari subjektifitas dari akademisi, studi Islam secara objektif memang membutuhkan beragam pendekatan guna memahami dan meneliti lebih dalam hal-hal yang terkait dengan Islam yang memang memiliki multi dimensi. 
Studi Islam secara garis besar dapat dilihat dari dua sudut pandang yaitu insider dan outsider. Dalam kategori ini, sebagian sarjana mempersoalkan apakah kajian yang dilakukan oleh kedua tipologi pandangan tersebut objektif dan dapat dipertanggungjawabkan. Hal ini mengingat kedua jenis pengkaji tersebut bagaimana pun dipengaruhi oleh latar belakang sosio-historis masing-masing mereka yang sangat mungkin memengaruhi objektifitas kajiannya. Bahkan, banyak kalangan memandang negatif pada outsider karena mereka berasal dari eksternal Islam. Pandangan negatif ini bukan tanpa alasan, sebab sangat mungkin outsider diikuti oleh kepentingan-kepentingan yang tak konstruktif bagi Islam dan masyarakatnya (Fanani, 2010).

Sejalan dengan persoalan tersebut, artikel ini seperti telah disebutkan di awal mendiskusikan persoalan metodologi dalam studi Islam. Topik ini dieksplor lebih lanjut dengan melihat pandangan pemikir Islam yang dikategorikan sebagai insider. Untuk kepentingan ini, bagaimana metodologi dalam studi Islam diurai dengan mendeskripsikan dan mengungkap pandangan intelektual dari Iran, yakni Ali Syariati. Tokoh revolusi Iran ini dalam beberapa tulisannya telah mengungkap pentingnya aspek metodologi dalam studi Islam yang menunjukkan pemikirannya. Studi pemikiran Ali Syariati tentang hal ini menurut penulis signifikan dilakukan. Sebab, kajian-kajian pemikiran tokoh revolusi Iran ini kebanyakan meninjau sisi pemikiran revolusi dan kiprah sosio-politiknya. Memang terdapat sejumlah artikel yang mengelaborasi pemikiran Ali Syariati terkait studi Islam. Namun, artikel-artikel tersebut masih kurang cukup dalam mengungkap bagaimana perspektif tokoh tersebut tentang studi Islam. Lebih dari itu, analisis terhadap pemikiran Ali Syariati juga signifikan dalam upaya memperkaya studi-studi pemikiran tokoh muslim abad 20 seperti yang telah dilakukan oleh beberapa sarjana terdahulu (Z Zulkifli, 2014; Indah Muliati dkk., 2020; Muslina \& Rahman, 2021; Amin, 2021).

\section{Metode}

Elaborasi pemikiran Ali Syariati tentang metode studi Islam dalam artikel ini dilakukan dengan metode deskriptif kualitatif. Dengan metode ini, data pemikiran Ali Syariati yang tertuang dalam karya tulisnya dianalisis dengan pendekatan filosofis dan teologi Islam. Data yang digunakan dalam artikel ini semuanya diperoleh dari sumber kepustakaan dan beberapa artikel ilmiah yang tersebar dibeberapa jurnal ilmiah online. Adapun karya Ali Syariati yang diperoleh dari sumber kepustakaan antara lain adalah Fatimah Az-Zahra: Pribadi Agung Putri Rasulullah, Membangun Masa Depan Islam, Tentang Sosiologi Islam, Ummah dan Imamah, Islam Agama Protes, dan On The Sociologi of Islam. Adapun inti pembahasan artikel ini dibagi menjadi tiga subbahasan yang meliputi biografi singkat Ali Syariati, pemikirannya tentang metode studi Islam, analisis, dan ditutup dengan kesimpulan.

\section{Hasil dan Pembahasan}

\section{Sejarah Kehidupan Ali Syariati}

Ali Syariati adalah salah satu di antara para pemikir Iran yang sangat gundah dengan fenomena kemunduran agama (Syi'ah) (Shimogaki, 1993). Latar belakang historis saat ia tumbuh dan berkembang menjadi intelektual terkemuka adalah kekuasaan Syah Reza Pahlevi yang mengumbar ketidakadilan dan kesewenang-wenangan. Para ulama Syi'ah kebanyakan bungkam atau mengambil sikap diam dan menjaga jarak dengan sosio-politik kala itu (Nugroho, 2007). Ali Syariati tampil dalam konteks ini untuk melontarkan gagasan-gagasan radikal dan mengecam para ulama yang telah menjadikan Syi'ah semata-mata sebagai agama berkabung (Rahnema, 2002).

Menurut Ali Syariati, para ulama telah memberlakukan al-Qur'an sebagai lembaran kering, tanpa makna, sementara pada sisi lain asik dengan isu-isu yang tidak penting seperti soal pakaian, ritual, panjang pendeknya jenggot dan semacamnya. Akibatnya ulama gagal memahami makna istilah-istilah kunci seperti ummah, imamah, dan nizam al-tauhid (Ridwan, 1999). Ulama yang digambarkan Ali Syariati lebih cenderung figh oriented dan senang bergumul dengan wacana khilafiyah yang semua itu tidak terkait dengan problem real 
masyarakat. Kemiskinan, kebodohan, dan keterbelakangan serta penindasan menjadi isu yang tak tersentuh (untouchtable) dalam alam pikiran para ulama sehari-hari, karena mereka lebih disibukkan dengan polemik wacana fiqhiyyah yang tidak urgen.

Ali Syariati lahir pada tanggal 24 November 1933 di desa Kahak yang merupakan tempat keluarga ibunya tinggal (Esposito, 1995; Rahnema, 1996, 2002). Kelahirannya bertepatan dengan periode ketika ayahnya menyelesaikan studi keagamaan pada tingkat dasar dan kemudian mengajar di sekolah dasar Syerafat (Syariati, 2008). Lingkungan keluarga yang religius dan progresif berpengaruh terhadap kepribadian Ali Syariati. Mentalitas, jati diri, dan intelektualitasnya terbentuk secara matang, utamanya lewat peran seorang ayah yang menjadi "guru sejati" dalam hidupnya.

Ali Syariati berasal dari keluarga religius yang tinggal di Mazinan, sebuah dusun kecil yang terletak di pinggiran gurun Kavir di propinsi Khurasan (Syariati, 1982; Rahnema, 2002). Keluarga tersebut terkenal salih, suka membantu masyarakat dan zuhud. Dalam keluarga ini ritual dan ritus keagamaan ditunaikan dengan seksama. Islam dalam pandangan keluarga ini adalah doktrin sosial dan filsafat yang relevan dengan zaman modern, dari pada sebagai keyakinan masa lalu yang bersifat pribadi dan hanya memikirkan dirinya sendiri (Suwito, 2004).

Sejak kecil Ali Syariati sudah memunculkan karakteristik yang berbeda dengan temanteman sebayanya. Ia mulai belajar menimba ilmu pendidikan dasarnya di Masyhad, yaitu sekolah swasta Ibn Yamin, tempat ayahnya mengajar (Rahnema, 2002). Ali Syariati kecil terkenal pendiam, tidak mau diatur, namun dirinya sangat rajin. Selain itu, dia juga selalu menyendiri, acuh tak acuh dengan dunia luar, sehingga tampak kurang bermasyarakat. Ali Syariati lebih sering mengurung diri di rumahnya dan menghabiskan waktunya dengan membaca bersama bapaknya hingga menjelang pagi.

Ali Syariati memulai pengalaman sekolah formalnya di tingkat pertama sekolah swasta Ibn Yamin tahun 1941 (Rahnema, 2002). Di sekolah, Ali Syariati mempunyai dua perilaku yang berbeda. Dia pendiam, tak mau diatur, dan rajin. Dia dipandang sebagai penyendiri, tak punya kontak dengan dunia luar, dan acuh tak acuh. Karena itu ia tampak tidak bermasyarakat. Di kelas, ia selalu memandang ke luar jendela, tak memperhatikan dunia di sekelilingnya. Di rumah, waktu Ali Syariati lebih banyak dihabiskan untuk membaca bukubuku milik ayahnya, sehingga melupakan buku-buku pelajaran yang diwajibkan oleh sekolah ataupun pekerjaan rumah. Buku yang sempat dibacanya saat itu adalah Les Miserables karya Victor Hugo ${ }^{1}$ serta buku-buku dengan topik variatif seperti vitamin dan sejarah sinema (Lestari, n.d.; Izetbigovic, 2010). Namun bila melihat perilakukanya yang senang menyendiri selama periode ini, dapat dikatakan bahwa pendidikan Ali Syariati di rumah menjadikannya terlalu mandiri di tengah masyarakat.

Ali Syariati mempelajari dan mendapat inspirasi dari karya-karya Saddeq-e Hedayat, Akhavan-e Saless, dan Maurice Maeterlinck. Ia sangat terkesan dengan sebuah pertanyaan Maeterlinck: "Bila kita meniup mati sebatang lilin, kemanakah perginya nyala lilin itu?" Pertanyaan yang cukup kritis tersebut memberi inspirasi yang besar dalam pikiran Ali Syariati (Rahnema, 2002). Pada tahun 1950 setelah menyelesaikan sekolah menengah atas, Ali Syariati mulai menjadi mahasiswa pada lembaga pendidikan Primary Teacher's Training College (Kolose Pendidikan Guru) di Masyhad. Sambil menuntut ilmu di bangku kuliah, Ali Syariati memulai karier menjadi pengajar (Syariati, 1998) dan sudah memberi kuliah kepada

${ }^{1}$ Victor Hugo dilahirkan di Besancon, Perancis, 26 Februari 1802. Nama lengkapnya adalah Victor Marie Comte Hugo, putra seorang jenderal yang cukup terkemuka di zaman Napoleon. Ia adalah salah satu penulis aliran romantisme pada abad ke-19 dan sering dianggap sebagai salah satu penyair terbesar Perancis. Karya puisinya yang dianggap sangat menonjol di antaranya adalah Les Contemplations dan La Légende des siècles. Walaupun sangat konservatif pada masa mudanya, ia berpindah ke aliran kiri pada masa tuanya. Ia menjadi pendukung aliran republikanisme dan Uni Eropa. Hasil karyanya menggambarkan hampir semua isu politik dan sosial, serta kecenderungan artistik pada zamannya. 
mahasiswa dan kaum intelektual di "Pusat Pengembangan Dakwah Islam" serta mengajar di Sekolah Dasar selama empat tahun. Selama periode tersebut ia mennerjemahkan surat Kasyf al-Gita untuk Gerald Ivan Hopkins, wakil presiden "Paguyuban Amerika" di Timur Tengah, yang berisi tentang keluhan dan protes dunia Islam terhadap Barat (Supriyadi, 2003).

Pada tahun 1952, Ali Syariati lulus dari Primary Teacher's Training College di Masyhad (Rahnema, 2002). Tiga tahun kemudian, saat usianya menginjak 23 tahun, Ali Syariati masuk fakultas Sastra Universitas Masyhad yang baru saja diresmikan (Ridwan, 1999). Bakat dan pengetahuan serta kesukaannya pada sastra menjadikannya populer di kalangan sesama mahasiswa. Pada masa ini, Ali Syariati cukup terkenal di kalangan lingkungan politik dan intelektual. Dia bukan saja mewujudkan bakat sastranya dalam syair-syair, namun juga berupaya keras mengindentifikasi dan menguraikan secara garis besar penjelasan nonkonvensional, progresif dan modernis tentang Islam.

\section{Metodologi dalam Studi Islam}

Metode studi Islam dapat dikatakan merupakan usaha komprehensif menggunakan berbagai pendekatan untuk mempelajari Islam dan masyarakatnya (Nurhakim, 2004). Ali Syariati memandang metode pendekatan sengat sensitif karena berkaitan dengan aspek kemajuan dan kemerosotan seperti dalam sejarah Eropa. Eropa mengalami stagnasi selama seribu tahun pada zaman pertengahan. Namun, setelah itu terjadi revolusi bidang ilmu pengetahuan, seni, sastra dan semua aspek sosial kemasyarakatan yang mengubah peradaban Eropa semakin maju (Syariati, n.d.). Analisis Ali Syariati terhadap sejarah Eropa tersebut adalah faktor metode analogis Aristoteles yang menyebabkan stagnasi pemikiran, peradaban dan budaya Eropa (Syariati, n.d.), namun ketika cara melihat berbagai masalah berubah, maka ilmu pengetahuan dan masyarakat Eropa juga berubah.

Terlepas dari kasus perubahan kebudayaan Eropa tersebut, pendekatan dan metodologi menurut Ali Syariati adalah faktor utama perubahan budaya, pemikiran, dan ilmu pengetahuan secara umum (Syariati, 1997). ${ }^{2}$ Pandangan yang sama juga dikemukakan oleh Mukti Ali. Menurut sarjana Indonesia ini yang menentukan dan membawa stagnasi dan masa kebodohan bukan karena ada atau tidaknya orang-orang jenius melainkan karena metode penelitian dan cara melihat sesuatu (A. M. Ali, 1990). Menurut Ali Syariati, metode studi Islam merupakan ilmu penting guna meninjau beragam pendekatan dalam memahami Islam. Diperlukan berbagai pendekatan untuk memahami Islam karena agama ini multi dimensi. Islam bukan semata-mata didasarkan pada perasaan-perasaan mistis manusia, atau hanya pada hubungan antara Tuhan dengan manusia. Dimensi akidah diperlukan metode filsafat untuk memahaminya, namun di sisi lain memahami Islam juga memerlukan pendekatan sosiologi dan sejarah karena berhubungan dengan cara hidup manusia di bumi. Ali Syariati menganologikan jika meninjau Islam hanya dari satu sudut padang saja, maka akan terlihat hanya satu dimensi dari sebuah kristal (Syariati, n.d.).

Mukti Ali juga sependapat dengan Ali Syariati, menurutnya apabila Islam dilihat dari satu segi saja, maka yang terlihat hanyalah satu dimensi dari fenomena-fenomena yang multiface sekalipun benar (A. M. Ali, 1997). Beberapa sarjana Islam lain juga memiliki pandangan yang sama dengan kedua sarjana di atas. Nasruddin Razak yang dikutip oleh Abuddin Nata menegaskan bahwa memahami Islam secara menyeluruh adalah penting walaupun tidak secara detail. Cara tersebut ditempuh sebagai upaya menghindari

${ }^{2} \mathrm{Abad}$ ke empat dan kelima sebelum masehi, ada jenius-jenius besar yang tidak dapat dibandingkan dengan jenius-jenius abad empat belas, lima belas dan enam belas. Aristoteles lebih jenius daripada Regor Bacon, tetapi bagaimana bisa orang-orang yang memiliki tingkat kejeniusan lebih rendah daripada Aristoteles mampu meletakkan dasar-dasar bagi kemajuan ilmu pengetahuan. Sebaliknya para jenius besar itu telah menyebabkan ribuan tahun stagnasi dunia. Begitu juga yang terjadi dalam peradaban Yunani. Banyak orang jenius sebelum Masehi berkumpul di Athena, tetapi tidak satu roda pun ditemukan di sana. Sebaliknya di Eropa dewasa ini, seorang teknisi awam yang bahkan tidak dapat memahami Aristoteles dan kata-katanya telah menemukan ratusan penemuan. 
kesalahpahaman yang dapat menimbulkan sikap dan pola hidup beragama yang salah pula (Nata, 2006). Islam harus dipahami secara utuh dan konprehensif. Hal ini perlu dilakukan untuk melengkapi metode pemahaman Islam yang selama ini berkembang dalam masyarakat, di mana Islam yang difahami dan dipraktikkan hanya berorientasi dari sudut pandang fiqh semata. Sementara di mensi Islam lainnya seperti tauhid, akhlak, tasawuf sejarah, tafsir, ekonomi dan politik dan lain-lain sepertinya kurang membumi.

Lebih lanjut Ali Syariati mengatakan bahwa ada berbagai cara memahami Islam. Cara-cara tersebut menurutnya meliputi berbagai pendekatan dan dimensi. Dalam hal ini ia menegaskan hanya menguraikan melalui pendekatan sejarah dan sosiologi karena ini adalah bidang kajiannya. Karena itu, dalam upaya memahami agama Islam, Ali Syariati mengumpamakan agama dengan seorang individu. Untuk mengenal individu yang merupakan pribadi besar hanya dapat dilakukan dengan dua cara sekaligus menurut Ali Syariati, yaitu mengenal pribadinya dan meninjau latarbelakang kehidupannya. Mengenal pribadinya menurut meliputi megetahui pemikiran, tulisan, saran, ceramah, artikel, dan buku-bukunya. Dengan kata lain, mengenal pemikiran dan ide-ide seseorang agar mengenal pribadinya (Syariati, n.d.).

Adapun mengatahui latar belakang kehidupannya akan melengkapi cara yang pertama di atas. Dalam hal ini perlu ditinjau kehidupan dan latar belakang keluarganya, dimana dia dilahirkan, apa ras dan bangsanya, bagaimana dia melewati masa kanak-kanaknya, bagaimana dia dibesarkan, di mana dia belajar, siapakah guru-gurunya, peristiwa apakah yang pernah ia alami dalam hidupnya, baik berhasil maupun gagal. Seperti perumpamaan di atas, dalam agama ada berbagai karya dan pemikiran seperti kitabnya yang membentuk suatu mazhab serta mengajak manusia untuk mengikutinya. Biografi dan gambaran agama membentuk sejarahnya. Jadi ungkap Ali Syariati, mengenal Islam secara tepat dan rinci merupakan standar hingga kini (Syariati, n.d.). Berdasarkan analogi di atas, menurut Ali Syariati ada dua cara utama untuk mengenal dan memahami agama Islam. Cara pertama adalah mempelajari al-Qur'an. Al-qur'an merupakan kumpulan pemikiran dan gagasan serta ilmu kepribadian Islam. Dalam sepanjang sejarah, ilmu pengetahuan telah ditarik dari alQur'an. Al-Qur'an sendiri menurutnya memiliki banyak dimensi seperti sastra dan lingustik, teologi, filosofis dan keimanan yang menjadi bahan pemikiran.

Ali Syariati juga menyebut dimensi al-Qur'an yang paling penting dan sedikit diketahui adalah aspek manusianya. Aspek ini terdiri dari berbagai dimensi seperti dimensi sosial, sejarah, dan psikologi (Syariati, n.d.). Selain itu, berbagai peristiwa sejarah yang berhubungan dengan suku-suku, nasib berbagai bangsa, hubungan mereka serta sebab-sebab kemerosotasnya juga disebutkan dalam al-Qur'an, khususnya dalam ayat-ayat yang panjang. Dalam bukunya yang lain, Ali Syariati mengatakan bahwa Allah Swt menyusun kitab alQur'an atas dasar dan bentuk hukum alam sehingga mirip dengan alam. Karena itu, untuk mengenal pemikiran-pemikiran Qur'an haruslah menggunakan metode-metode yang benar yang ditempuh para pengkaji ilmu alam dan kemanusiaan (Syariati, 1990).

Cara kedua menurut Ali Syariati dalam memahami Islam adalah mempelajari sejarah Islam yang menggambarkan berbagai perubahan yang terjadi dari awal misi kenabian hingga sekarang (Syariati, n.d.). Sejarah adalah suatu ilmu yang di dalamnya dibahas berbagai peristiwa dengan memperhatikan unsur tempat, waktu, objek, latarbelakang, dan pelaku dari peristiwa tersebut (Abdullah, 1987). Melalui pendekatan sejarah pembahasan berangkat dari idealis kepada empiris dan mendunia. Sejarah seperti ilmu-ilmu lain, menyingkap kaedahkaedah keilmuan, pertalian luhur yang menghubungkan peristiwa-peristiwa kemanusian sepanjang masa lalu sampai sekarang (Syariati, 1990). Dengan demikian, mempelajari sejarah Islam meliputi berbagai peristiwa dan kejadian yang benar-benar terjadi, yang berkaitan dengan pertumbuhan dan perkembangan agama Islam dalam berbagai aspek.

Di samping kedua cara tersebut, Ali Syariati juga menawarkan cara lain dalam memahami agama Islam. Cara atau metode yang ditawarkan oleh Ali Syariati adalah 
pendekatan tipologi sebagaimana yang berkembang dalam ilmu sosiologi (Syariati, n.d.). Menurut Mukti Ali, metode ini dipergunakan oleh para sosiolog karena dianggap objektif berisi klasifikasi topik dan tema sesuai dengan tipenya. Karena itu, metode ini juga dapat dipergunakan untuk memahami agama Islam (A. M. Ali, 1997). Lebih jauh Ali Syariati mengatakan, kebanyakan sosiolog dewasa ini percaya kepada metode tipologi sebagai pendekatan terbaik untuk memecahkan berbagai masalah sosiologi khususnya dalam studi perbandingan antar mazhab pemikiran. Metode tipologi meliputi beberapa tema pembahasan seperti mengenal Allah Swt., Kitab, Kenabian, obyek da'wah, dan para pengikut pilihan. Ruang lingkup tipologi tersebut juga diakui oleh Mukti Ali (1997).

\section{a. Allah Swt.}

Menurut Ali Syariati, untuk memperoleh ilmu tentang Islam dan sistem yang ada di dalamnya, pertama-tama harus mengenal Allah Swt (Syariati, n.d.). Dalam ilmu tauhid, ada dua cara yang dapat digunakan untuk mengenal Allah Swt. yaitu melalui wahyu dan melalui ciptaan Allah Swt. Hal ini juga dinyatakan juga oleh Ali Syariati, mengenal Allah Swt. menurutnya dapat dilakukan dengan mengenal makhluk-makhluk-Nya, melalui filsafat dan penerangan jiwa (soul illumination), melalui mistik atau dengan penelitian atas rinciannya. Namun, yang dimaksud dengan mengenal Allah Swt. dalam hal ini tetap menggunakan pendekatan tipologi.

Pendekatan tipologi yang dimaksud adalah mempelajari jenis, asal usul, mode, konsep dan sifat-sifat Allah Swt. sebagai contoh misalnya apakah Dia Maha Kuasa, apakah Dia Maha Penyayang, apakah Dia Maha Tinggi di atas segalanya, apakah Dia berbaur dengan manusia, apakah aspek Maha Kasih-Nya mengungguli aspek Maha Kuasa-Nya atau sebaliknya. Ringkasnya menurut Ali Syariati, Tuhan seperti apakah Dia, Ali Syariati menyatakan untuk memperoleh ilmu yang tepat tentang sifat-sifat ini, harus merujuk kepada al-Qur'an, kata-kata Nabi atau kepada para pengikut khusus yang di didik oleh Nabi. Menurutnya, sifat-sifat tersebut diungkapkan dalam al-Qur'an atau melalui petunjuk Nabi serta pengikutnya di mana mereka membandingkan Allah Swt. dengan Tuhan-Tuhan lain yang dilkukiskan dalam agama-agama lain (Syariati, n.d.).

\section{b. Mengenal kitab}

Langkah kedua menurut Ali Syariati untuk mempelajari Islam adalah dengan mengenal al-Qur'an (Syariati, n.d.). Dalam hal ini, aspek yang dikaji adalah mempersoalkan kitab macam apakah al-Qur'an. Masalah-masalah apakah yang diperhatikan di dalamnya, apakah al-Qur'an lebih banyak berbicara tentang kehidupan di muka bumi ataukah kehidupan setelahnya yakni akhirat. Apakah ajaran al-Qur'an lebih banyak ditujukan kepada individu dan berbagai masalah moral atau aspek sosial. Apakah al-Qur'an lebih banyak merujuk kepada materi atau ruhani, dan apakah lebih menaruh perhatian kepada alam atau individu. Masalah-masalah apakah yang al-Qur'an perhatikan dan bagaimana bentuknya.

\section{c. Mengenal Nabi}

Langkah ketiga untuk mengenal Islam menurut Ali Syariati adalah dengan mengenal Nabi Islam yakni Muhammad bin Abdullah. Mengenal Nabi Islam penting bagi seorang sejarawan, karena dalam pandangannya, tidak ada seorangpun yang pernah memiliki tanggungjawab yang dibebankan kepada Nabi melalui peristiwa yang amat dahsyat. Ketika berbicara tentang kepribadian Nabi, niat yang harus dipasang adalah untuk melihat bagaimana beliau memperhatikan manusia dan bagaimana hubungan beliau dengan Allah Swt. Dengan kata lain, mengenal Nabi adalah merenungkan dimensi manusianya dan misi kenabiannya. Dalam melihat dimensi manusianya, yang perlu diperhatikan adalah mempelajari cara bicaranya, berjalan, berpikir, tertawa, duduk dan tidurnya. Juga mengetahui hubungannya dengan orang-orang asing, musuh, sahabat, dan keluarga serta kekalahan-kekalahan, kemenangan-kemenangan dan reaksinya terhadap berbagai masalah sosial (Syariati, n.d.). Dengan demikian, bagian terpenting mengenal kebenaran, jiwa dan 
realitas Islam yang utama menurut Ali Syariati adalah mengenal Nabi dan kenabiannya serta membandingkannya dengan tokoh-tokoh agama lainnya yang ada dalam sejarah.

\section{d. Mengenal obyek dakwah}

Langkah selanjutnya untuk memahami Islam menurut Ali Syariati adalah mempelajari sifat kenabian Islam. Dalam hal ini misalnya apakah beliau tampil tanpa persiapan, apakah ada orang yang sedang menati-menantikan beliau. Apakah beliau mengetahui misi beliau, apakah misi itu tiba-tiba datang kepada beliau dan mengubah cara bicara atau kepribadian beliau dengan suatu cara yang pada awalnya sulit bagi beliau. Gerakan apakah yang muncul ketika beliau hadir. Lebih condong ke kelas apakah beliau, kelas apakah yang beliau perangi. Jawabab-jawaban pertanyaan tersebut akan membantu dalam mengenal Nabi dan juga mengenal sifat keadaan beliau (Syariati, n.d.). Semua Nabi, dengan pengecualian sebagian dari Nabi-nabi Ibrahimi, mengakuai kekuasaan yang ada pada zamannya dan mencapai misinya dengan bantuan kekuasaan. Sebaliknya, Nabi-nabi Ibrahimi dari Nabi Ibrahim sampai Nabi Muhammad Saw. hadir dalam bentuk pemberontakan terhadap kekuasaan yang ada. Dengan demikian, membandingkan Nabi-nabi tersebut akan sangat membantu dalam mengenal kebenaran, ruh dan arah agama-agama ini.

\section{e. Mengenal pengikut pilihan}

Langkah terakhir mengenal Islam menurut Ali Syariati adalah dengan mempelajari orang-orang yang membentuk unsur-unsur yang membangun manusia-manusia yang berbeda dan terkemuka. Mengenal orang-orang tersebut secara jelas dan ilmiah adalah seperti mengenal sebuah pabrik melalui barang-barang yang diproduksinya, hal ini disebabkan karena agama seperti pabrik yang membangun manusia. Oleh karena itu, Ali Syariati memiliki pandangan bahwa dalam rangka mengenal dan memahami agama Islam perlu mengenal Husein sebagai model, lalu membandingkannya dengan Ibnu Sina atau al-Hallaj (Shariati, n.d.).

Akhirnya, terlepas paragraf terakhir memperlihatkan kecenderungan Syi'isme dalam pikiran Ali Syariati, metode tipologi yang ditawarkan tak dipungkiri cukup penting dalam memahami Islam. Mengenal dan memahami Islam logisnya memang perlu memahami Tuhan dalam Islam, kitab suci Islam, aktor-aktor dalam sejarah Islam termasuk Nabi dan sahabat serta umatnya. Namun, kecenderungan metoda ini memperlihatkan posisi Islam sebagai agama dalam realitas budaya yang ditinjau dari luar. Meski demikian, hal penting yang perlu dicatat dalam pemikiran Ali Syariati sebagai tokoh modernis Iran abad ke 20 adalah kesadarannya bahwa memahami Islam memerlukan metodologi yang komprehensif, bukan hanya semata dari aspek teologi. Gagasan ini menempatkannya sejajar dengan modernis Indonesia abad ke 20 seperti Mukti Ali dan Harun Nasution yang juga cenderung menekankan mempelajari Islam mesti dilakukan dari berbagai aspek bidang keilmuan (Nasution, 1985).

\section{Analisis pemikiran Ali Syariati}

Sub bab sebelumnya telah diuraikan pemikiran-pemikiran Ali Syariati tentang metode memahami Islam. Secara umum, Ali Syariati melihat bahwa Islam perlu dipahami melalui berbagai pendekatan agar konfrehensif dan tidak parsial. Beberapa bentuk contoh pendekatan disebutkan oleh Ali Syariati seperti pendekatan sosiologi, sejarah, dan antropologi. Hal ini menurutnya disebabkan Islam sendiri bukanlah agama yang memiliki satu dimensi, tetapi Islam adalah agama yang memiliki berbagai dimensi kehidupan manusia. Perlunya memahami Islam secara konfrehensif juga disebutkan oleh beberapa intlektual muslim lainnya seperti Nasruddin Razak. Islam menurutnya dapat dipahami secara luas dan utuh dengan empat cara yaitu dengan mempelajari sumber asli Islam yakni al-Qur'an dan hadits, 
memahami Islam secara integral ${ }^{3}$, mempelajari karya-karya para $u \mathrm{uma}^{4}$, dan secara normatif teologis 5 .

Pendapat yang sama juga disebutkan oleh Mukti Ali bahwa Islam harus dipelajari secara konfrehensif. Begitu pula yang disebutkan oleh Abuddin Nata, mempelajari agama dapat dilakukan dengan berbagai pendekatan sehingga akan komprehensif dan tidak parsial. Beberapa pendekatan yang dapat digunakan seperti teologi normatif ${ }^{6}$, antropologis ${ }^{7}$, sosiologis $^{8}$, filosofis ${ }^{9}$, historis, kebudayaan dan psikologi (Nata, 2006). Hal senada juga diungkapkan oleh Sayuthi Ali, namun dengan nada sedikit berbeda, dimana ia tidak menggunakan filsafat sebagai suatu pendekatan, namun menggunakan ilmu pendidikan, pendekatan kualitatif dan kajian agama (S. Ali, 2002).

Selain bersifat komprehensif, untuk memahami Islam diperlukan pendekatan lain yang oleh Ali Syariati disebut dengan memahami al-Qur'an. Pendekatan ini dalam studi kontemporer disebut dengan pendekatan sumber asli, di mana untuk mengenal dan memahami suatu agama dilakukan dengan menelaah sumber-sumber asli agama tersebut. Hal ini sebenarnya juga di akui oleh Ali Syariati sendiri dan para cendikiawan muslim masa kini. Hanya saja, pendekatan sumber asli yang ditawarkan oleh Ali Syariati lebih cendrung filosofis dan sosiologis, bukan dalam bentuk kajian teks dan doktrin, isi atau kebahasaan. Hal ini terlihat dari argumen-argumennya yang menggunakan logis relistis sebagai acuan dan mengaitkannya dengan kehidupan manusia.

Begitu pula dengan pendekatan sejarah yang ditawarkan oleh Ali Syariati. Pendekatan ini merupakan metode yang sudah umum digunakan oleh para sejarawan dan sosiolog terutama Barat. Jika pendekatan ini dilihat dari sudut epistemologi Islam akan terlihat bahwa pendekatan ini mirip dengan kajian tarikh dalam Islam. Selain itu, dalam kajian keislaman juga dikenal beberapa studi yang lebih dulu muncul ketimbang ilmu sejarah itu sendiri seperti kajian asbab nuzul dan lain-lain. Adapun pendektan tipologi dalam memahami Islam seperti yang di sebutkan oleh Ali Syariati dan juga Mukti Ali juga merupakan metode yang berkembang dan diterapkan di Barat.

Uraian-uraian di atas menunjukkan metode yang dapat digunakan untuk memahami Islam secara garis besar ada dua macam. Pertama, metode komparasi, yaitu suatu cara memahami agama dengan membandingkan seluruh aspek yang ada dalam agama Islam tersebut dengan agama lain. Dengan cara demikian akan menghasilkan pemahaman Islam yang objektif dan utuh. Kedua, metode sintesis, yaitu suatu cara memahami Islam yang memadukan antara metode ilmiah dengan segala cirinya yang rasional, objektif kritis, dan dengan metode teologi normatif. Metode ilmiah digunakan untuk memahami Islam yang

\footnotetext{
${ }^{3}$ Artinya Islam dipelajari secara menyeluruh sebagai satu kesatuan yang bulat tidak secara sebagian saja.

${ }^{4}$ Dalam hal ini mempelajari karya-karya ulama mengingat pada umumnya mereka memiliki pemahaman Islam yang baik, yaitu pemahaman yang lahir dari perpaduan ilmu yang dalam terhadap alQur'an dan Sunnah Nabi dengan pengalaman yang indah dari praktik ibadah yang dilakukan setiap hari.

${ }^{5}$ Pendekatan normative teologis adalah mempelajari Islam yang ada dalam al-Qur'an kemudian menghubungkannya dengan kenyataan histories, empiris, dan sosiologis masyarakat. Dengan demikian akan diketahui kesesuaian atau kesenjangan antara Islam yang berada pada tataran normative teologis dengan Islam yang ada pada tataran histories, sosiologis dan empiris.

${ }^{6}$ Pendekatan ini merupakan cara memahami agama dengan menggunakan kerangka ilmu ketuhanan yang betolak dari suatu keyakinan bahwa wujud empiric dari suatu keagamaan dianggap sebagai yang paling benar dibandingkan dengan yang lainnya.

${ }^{7}$ Adalah upaya memahami agama dengan cara melihat wujud praktik keagamaan yang tumbuh dan berkembang dalam masyarakt.

${ }^{8}$ Adalah ilmu yang menggambarkan tentang keadaan masyarakat lengkap dengan struktur, lapisan serta berbagai gejala social lainnya yang saling berkaitan. Sosiologi dapat digunakan sebagai pendekatan dalam memahami agama karena banyak sekali ajaran agama yang berkaitan masalah social dan hanya dapat dipahami secara proporsional dan tepat bila menggunakan ilmu ini.

${ }^{9}$ Pendekatan filosofis berupaya memahami agama secara bijaksana. Pendekatan in bermaksud agar hikmah, hakikat atau inti dari ajaran agama dapat dimengerti dan dipahami secara seksama.
} 
tampak dalam kenyataan historis, empiris, dan sosiologis, sedangkan metode teologis normatif digunakan untuk memahami Islam yang terkandung dalam kitab suci.

Islam sebagai objek kajian dan penelitian dapat dikaji melalui berbagai pendekatan dan wilayah kajian seperti pokok-pokok ajaran agama, hasil pemikiran filosofis dalam agama, tingkah laku atau kehidupan keagamaan umat beragama dan sosial budaya yang memengaruhi perkembangan pemikiran dan kehidupan agama. Sebagai contoh kajian yang dilakukan oleh Abdul Halim (2008) yang menulis tentang politik hukum Islam di Indonesia. Halim menelaah posisi politik hukum Islam dalam politik hukum pemerintahan orde baru dan era refosemasi. Dalam kajian ini, Halim secara kualitatif mengelaborasi pendekatan sosiologi, legal, dan historis untuk mengeksplorasi pola-pola interaksi antara kekuatankekuatan politik dalam proses legislagi hukum Islam pada masa Orde Baru dan Era reformasi. Sejauh mana pola interaksi melahirkan posisi hukum Islam dan karakter hukum Islam pada kedua periode kekuasaan tersebut (Halim, 2008).

\section{Kesimpulan}

Pembahasan artikel ini menegaskan gagasan urgensi dan keniscayaan integrasi berbagai metode dalam pengkajian Islam. Eksplorasi pemikiran Ali Syariati (yang hidup dalam abad 20) tentang metode memahami Islam menjadi bukti dan argumen atas klaim tersebut. Dalam konteks realitas sosial politik umat Islam yang masih dibayangi tekanan dan hegemoni kolonialisme, Ali Syariati melihat metode memahami Islam secara komprehensif sangat penting dan mendasar bukan hanya karena Islam bersifat multi dimensi, namun lebih dari itu metode pendekatan berkaitan dengan aspek kemajuan peradaban. Tegasnya adalah pendekatan dan metodologi merupakan faktor utama perubahan budaya, pemikiran, dan ilmu pengetahuan secara umum. Ali Syariati tampaknya berupaya mendorong perubahan kesadaran masyarakat Iran untuk menggunakan berbagai metode dalam memahami Islam dalam rangka memajukan peradaban, dimana ketika itu dunia Islam baru merdeka dari kolonialisme dan masih jauh tertinggal dari Barat. Sayangnya, akibat keterbatasan bidang keilmuan, Ali Syariati hanya menawarkan dua kerangka metode dalam memahami Islam yaitu pendekatan ilmu sejarah dan sosiologi.

\section{Daftar Kepustakaan}

Abdullah, T. (Ed.). (1987). Sejarah dan Masyarakat. Pustaka Firdaus.

Ali, A. M. (1990). Metodelogi Ilmu Agama Islam. In T. A. dan M. R. Karim (Ed.), Metode Penelitian Agama Sebuah Pengantar (p. 44). Tiara Wacana Yogya.

Ali, A. M. (1997). Ilmu Perbandingan Agama. Gajah Mada University Press.

Ali, S. (2002). Metodologi Penelitian Agama; Pendekatan Teori dan Praktik. Raja Grafindo Persada.

Amin, K. (2021). Teosofi al-Suhrawardi al-Maqtul dan Mahzab Iluminasionisme dalam Filsafat Islam Khairul Amin. 2(2), 99-108.

Chojim, A. (2007). Syeikh Siti Jenar: Makrifat dan Makna Kehidupan. Serambi Ilmu Semesta.

Dkk., I. M. (n.d.). View of Pemikiran Pendidikan Muhammad Abduh. Al-Kawakib: Jurnal Kajian Keislaman, Vol 1 No., 44-53. Retrieved December 27, 2021, from http://kawakib.ppj.unp.ac.id/index.php/kwkib/article/view/12/13

Esposito, J. L. (1995). The Oxford Encyclopedia of The Modern Islamic World. Oxford University Press.

Fanani, M. (2010). Metode Studi Islam. Pustaka Pelajar.

Gaus, A. (2010). Api Islam Nurcholish Madjid. Kompas.

Halim, A. (2008). Politik Hukum Islam di Indonesia, Kajian Posisi Hukum Islam dalam Politik Hukum Pemerintahan Orde Baru dan Era Reformasi. Badan litbang dan Diklat 
Departemen Agama RI.

Izetbigovic, A. 'Ali. (2010). Islam Between East and West. Islamic Book Trust.

Jazuli, A. S. (2006). Kehidupan dalam Pandangan Al-Qur'an.

Lestari, K. D. (n.d.). Victor Hugo (1802-1885). www. pelitaku.sabda.org.

Muslina, M., \& Rahman, R. (2021). Pemikiran Pendidikan Islam Syekh Muhammad Naquib Al-Attas. Jurnal Kawakib, 2(1), 55-63. https://doi.org/10.24036/kwkib.v2i1.19

Nasution, H. (1985). Islam Ditinjau dari Berbagai Aspek. UI Press.

Nata, A. (2006). Metodelogi Studi Islam. Raja Grafindo Persada.

Nugroho, A. (2007). Islam Agama Pembebasan: Pandangan Ali Syari'ati. http://pemikiranislam.wordpress.com

Nurhakim, M. (2004). Metode Studi Islam. Universitas Muhammadiyah Malang.

Rahnema, A. (2002). Ali Shariati: Biografi Politik Intelektual Revolusioner. Erlangga.

Ridwan, M. D. (1999). Melawan Hegemoni Barat. Lentera.

Shariati, A. (n.d.). Islam Agama Protes. Pustaka Hidayah.

Shariati, A. (1982). Tentang Sosiologi Islam (S. Mahyudin (Ed.)). Ananda.

Shariati, A. (1990). Ummah dan Imamah (M. Faishal (Ed.)). Yapi.

Shariati, A. (1997). On The Sociologi of Islam. Mizan Press.

Shariati, A. (1998). Membangun Masa Depan Islam: Pesan untuk Para Intelektual Muslim (R. Astuti (Ed.)). Mizan.

Shariati, A. (2008). Fatimah Az-Zahra: Pribadi Agung Putri Rasulullah (M. H. Assagaf (Ed.)). Zahra.

Shimogaki, K. (1993). Kiri Islam: Telaah Kritis Pemikiran Hasan Hanafi antara Modernisme dan Postmodernisme (M. J. Maula (Ed.)). LKiS.

Supriyadi, E. (2003). Sosialisme Islam: Pemikiran Ali Shariati. Pustaka Pelajar.

Suwito. (2004). Transformasi Sosial: Kajian Epistimologi Ali Shariati Tentang Pemikiran Islam Modern. Unggun Religi.

UPI, T. P. I. P. (2007). Ilmu dan Aplikasi Pendidikan. Grasindo.

Z Zulkifli. (2014). Pemikiran Abdullahi Ahmed an-Na'Im Tentang islam Dan Negara. Jurnal Agama Dan Sosial Humaniora, XII, http://journal.1samaaceh.com/index.php/kalam/article/view/12/11 